\title{
The Assessment of the Effect of Firm Size on Competitiveness of Commercial Banks in Kenya
}

\author{
Moses O. Owino ${ }^{1 *}$ \\ Jonathan Mulwa ${ }^{2}$ \\ Janet Wagude ${ }^{3}$ \\ Rongo University, Rongo, Kenya ${ }^{1,2 \& 3}$
}

\begin{abstract}
Over the past few decades, Kenya's banking industry has been experiencing several challenges and upheavals. Thus, it is worth exploring the business strategies that banks adapt to survive and remain competitive in the banking industry. In establishing the nature of the relationship between the working environment and the outside environment, the size of a corporation plays a critical role. Therefore, the current study investigated the effect of firm size on the competitiveness of commercial banks in Kenya. The study adopted an Expost Facto research design to analyse data and establish relationships between variables. Ten-years secondary panel data collected on commercial banks of Kenya obtained from the Central Bank of Kenya database was utilised. Data was analysed inferentially using correlation and regression analysis. Descriptive statistics were utilised to summarise the data meaningfully. Results showed that commercial banks size (firm size) was positively correlated with the bank's competitiveness $(r h o=0.989, p<0.01)$. Commercial banks size significantly $(p<0.05)$ affects their competitiveness. Therefore, the study concludes that firm size significantly affected the competitiveness of commercial banks in Kenya, which many authors in works of literature greatly supported. Based on the outcome, microfinance investors should focus on increasing firm size to have an increment in the portfolio returns. Further, commercial banks should improve their capability by increasing their firm sizes.
\end{abstract}

Keywords: Firm Size, Commercial Bank Competitiveness, Banking Industry, Profit Maximization

*Corresponding author: Moses O. Owino; Email: owinomosesotieno@yahoo.com DOI: https://doi.org/10.37227/JIBM-2021-07-1089

\section{Introduction}

Firm size has, over the years, played a critical role in guaranteeing the stability of an economy's financial sector. In 2007/2008, global financial instability, large banks were undoubtedly responsible for a great deal of economic devastation. Consequently, the discussion on the best size of the company has thrived following the said financial instability (Vinals et al. 2013, and Laeven, Ratnovski, and Tong, 2014). Banks provide credit facilities and deposit services that facilitate business transactions, which are the leading players in economic development. While banks of all sizes offer clients and small enterprises credit services, larger banks possess more capital to meet the credit needs of major companies when they operate on a scale that allows for more efficient and 
specific banking services. In the study comparing smaller and large banks in the United States, Allen and Rai (2009) established that smaller banks favoured local economic factors, making them more competitive. On the contrary, large-sized banks favour fewer conditions in their immediate area because legal constraints and efforts to disseminate the risk of loans were reduced by the size of the loans. Further, larger banks extended enormous lending to big firms in remote regions using banking services in large territories. Large banks have acknowledged their consumers across the country and outside because the expansion of such banks has been partially dictated by local economic performance. Larger banks have increased access to resources, like ICT and research and development. These resources are vital for supporting banking innovations, such as new goods or services to suit a variety of client requirements such as access enhancement, being flexible and convenient and cost-cuts. According to Abubakar Aliyu and Tasmin (2012), one of the key reasons why big banks invest in technology, research, and development is that they are determined to provide the most effective provision of superior products or services. This helps to increase sales and cut operating costs.

Bigelli and Sánchez-Vidal (2012) define the firm's size in the form of its holdings of the assets. The authors state that large corporations have diversified their investment sectors, so reducing their risks means less likely becoming insolvable. Low bankruptcy rates allow larger companies to access greater debt amounts. Large businesses can lower the extent of market information asymmetry by benefitting from performance-enhancing possibilities on the market. Compared to smaller businesses, Marete (2015) indicated that large companies are more stable in meeting financial obligations and have a high level of exposure to information. As a result of their broad network of branches, large banks meet the financial demands of their consumers, unlike small banks, which do not serve these markets. On the same note, Willison, Dimitris \& Hong (2013) suggested that bank size's efficiency is determined by bank size because economies of scale vary according to a variety of feasible sizes of banking activities. Large banks have stronger market experience and well-defined networks, hence greater chances of settling on the market than smaller banks. In Kenya, there is growing competition in the banking industry due to some factors, such as the adoption of modern technologies and changing client requirements. In order to serve more clients and promote sales growth, microfinance banks must be competitive to boost their services' efficiency. In support of the above argument, Mwangi (2014) noted that efficiency remains a challenge for Microfinance banks, as most of them cannot afford new technologies to integrate and improve their processes.

Dietrich and Wanzenried (2011) investigated the factors that affected a bank's profitability before and during Switzerland's financial crisis. The findings showed that the profitability of both large and small banks was positive. In addition, the profitability of large and small banks relative to medium-sized banks before crises was also disclosed. One of the reasons bigger banks were profitable was that they had better services since they implemented new technology. By managing large products and services and using complicated systems and processes, the banks had diversified their products and services in order to limit risk. Mulwa (2020) believes that the size of a company refers to its competitive power and ability to use its resources on the market profitably. These findings have been confirmed in Foyeke, Iyoha, \& Ojeka (2015) study, which established a significant direct link between the size, financial achievement and voluntary corporate management divulgations. The study investigated the drivers of voluntary corporate governance disclosures among 137 companies in Nigeria. The findings demonstrate the trust larger and more successful banks have in disclosing information on business management. Several studies such as those conducted by Too and Simiyu (2019), Odusanya et al. (2018), and Kisengo and Kipchumba (2016) on the company performance determinants have recognised firm size as a predictor. But most of these researches focused on industrial and manufacturing companies or selected economic sectors. This does not mean that the size of the company significantly affects its success. However, with research revealing contradictory results on the impact of company size on performance, the precise impact remains unknown.

Muinamia and Atheru (2018) reported a strong direct effect on the return on assets among financial institutions; they analysed a 7-years (2009 to 2016) panel data of 8 banks in Kenya. Similar results were reported by Kipesha (2013); the author examined five years of effects of company size and age on the performance of microfinance institutions in Tanzania. Kipesha (2013) established a 
favourable impact on the sustainability, profitability and level of financial revenue for companies in terms of total assets, number of bonds, and number of employees. Like Kipesha (2013), Kisengo and Kipchumba (2016) also reported a favourable impact of company size on corporate performance among the 52 microfinance banks in Nakuru City. Kisengo and Kipchumba's research was however based on primary data, which, because of the dynamic nature of the firm dimension, makes the results inconclusive. On the contrary, Too and Simiyu (2018) reported the reverse impact on company return on equity among general insurance businesses in Kenya, using panel data for the period between 2011 and 2015. Comparably, Mulwa and Kosgei (2016) found an inverse influence of company size on the return on commercial banks' assets among commercial banks in Kenya using panel data for the years 2005 to 2013. This is due to the efficiency of small banks' relationships. In support, Eyigege (2018) also observed a substantial inverse impact in the financial performance of Nigeria Stock Exchange-listed five deposit cash banks using panel data from 2005 through 2016. Other studies had indifferent findings or employed approaches which cannot demonstrate the relationship between company size and performance. For instance, Mulwa and Kosgei (2016) in Kenya reported an insubstantial effect of firm size on the profitability of commercial banks using data from 2005 to 2013. On the same note, Maina, Kiragu, and Kamau (2019) found an insignificant effect of firm size after investigating a five-year relationship between corporate and profitable banks after analysing data from 43 banks from 2012 to 2016. Nonetheless, Maina, Kiragu and Kamau (2019) noted that the size of the firm and its financial performance are moderately positive. The quadratic or cubic relationship between the size and performance of the listed manufacturing enterprises could not be demonstrated in Turkey despite a linear relationship (Ozcan et al., 2017).

\section{Statement of Purpose}

With the rising competitiveness in the banking sector, banks must enhance their firm size in preparation for uncertain financial scenarios. This is because the stockholders and creditors must earn appropriate returns to exist and to satisfy their daily responsibilities. The bank's profitability and management variables are very important today, especially when the competition is fierce with dynamic customer expectations (Mwangi, 2018). Even so, the impact of firm size on its competitiveness is still uncertain. Previous research has provided inconclusive evidence and has not revealed a clear association between bank (firm) size and banks' financial performance. For example, Sritharan (2015) has demonstrated that the firm's size is associated positively with competitiveness. Therefore, there is a need to evaluate the actual impact and identify whether to support and reject the hypothesis.

\section{Research Purpose}

The current study aims to evaluate the effects of firm size in the Bank Diversification and competitiveness in Kenya.

\section{Research Hypothesis}

$\mathrm{H}_{01}$ : Firm size has no significant effect on the competitiveness of commercial banks in Kenya.

\section{Literature Review}

Several studies have explored the nexus between diversification, size and competitiveness of commercial banks. In their study conducted in the United States (USA) and Europe, Laeven, Ratnovski and Tong (2015) established that bank competitiveness was directly affected by banks size. The research's objective was to create a foundation for the disputed argument on the extent to which the bank's size is related to the systematic risk of the bank due to competition. The study used the SRISK approach to evaluate the contribution of a bank to systemic risk. The authors used facts from the then-recent financial crisis on the individual level of the companies. Their empirical results showed that larger banks, on average, have created more systemic risks than smaller banks as they face more competition. Even in instances of insufficient money, uncertain capital flows and organizationally complicated, bigger banks are taking major risks. Nevertheless, the more the dangers of insecurity, the greater the possibility that market-based operations will be competitive. 
Finally, Laeven, Ratnovski and Tong (2015) also established a positive association between the size of the bank and the amount of systemic risk whereby the bigger the bank, the greater the level of systemic hazards and the more competitive it becomes. Likewise, Krotel, Villadsen and Hansen (2017) noted that the motive of this migration has remained a crucial source for a multiplicity of queries from the researchers in growing the scale of organisations from the smaller to the larger categories. The objective of this study was to determine the place for size changes in public management. Prior to and after analysis reported important changes understood to have significantly affected the sizes of most municipalities in Denmark; the time of the survey data collection was intentionally planned. Findings showed that, from a public standpoint, corporate management is linked to daily business. Moreover, this was not usually affected by size. The key indicator was the overall responsibility of public management to develop an organisational vision, especially one articulated and promoted by the mayor, who manages to maintain external links, and who is connected to the change in size.

On the same note, Kamani (2018) conducted an empirical investigation on European banks. The author assessed the relationship between banks' size, non-traditional banking activity and the systemic risk facing European banks. Kamani (2018) used the generalised method of moments to acquire data from European banks and to consider common elements that cannot be noticed in banks. The results revealed that the systemic risk of smaller banks grew through depending on nontraditional operations. This was because it demonstrated that deposits at the asset ratio were comparatively lower to increased non-interest income. For smaller banks, systemic stability was therefore decreased. Kamani (2018) study demonstrated that, even in tiny institutions, trading activity raised its susceptibility to systemic hazards. When tiny banks are diversified, they rise in complexity and are therefore more complex and transparent. These banks are, therefore, primarily acclimated to riskier companies and increase their exposure to price volatility. Hakenes and Schnabel (2011) conducted a related investigation to determine the relationship between bank size and competitiveness as shown in 'Base II Capital Agreements Risks.' The research employed secondary methods of data collection from previously conducted studies in the German base nation. The methodologies were used to define the influence of small and large banks in the banking sector with a standardised and internal rate basis. The results showed that the Basel II Agreement negatively impacted small commercial banks by increasing the risk rate in the economy, hence making them less competitive than large banks. The interpretation of the results was that the Basel II approach to the capital agreement gave larger banks a competitive edge over smaller banks through raising risk level. The results of this investigation showed that the banks' size and competitiveness had a negative association.

More advocates of a commercial bank are considered to have a beneficial effect on corporate performance and competitiveness. On this note, Naseri, Bacha and Masih (2020) conducted a study to examine whether bank size has a good or negative influence on its competitiveness. The 12-year (2002 to 2013) examined 12 different countries through a quantitative experimental analysis. The authors evaluated bank size and GMM variables and found that bank size and performance are nonlinear in relation to profitability and efficiency. Banking size was equivalent to the increase in profitability and efficiency of commercial banks, which are crucial to competitiveness, both in conventional and Islamic banks. Naseri, Bacha and Masih (2020) proposed that commercial banks should upgrade their financial system's infrastructures to preserve this commerce. It has been advocated for small commercial banks to improve their size by finding additional, increasing leverages via acquisition and merger. The report also indicated that most banks in Islamic banking have modest banks that compete with conventional banks. From the results mentioned above, it was found that the size of the bank had a favourable impact on the competitiveness of the banks as seen for boosting profit and efficiency. Similarly, Maina, Kiragu and Kamau (2019) researched the relationship between bank size and commercial bank competitiveness in Kenya. The study's methodology was based on descriptive statistics, and additional data was gathered from secondary sources, such as firm annual reports and the Central Bank of Kenya database. The bank size was determined by the annual deposits and gross loans, while the competitiveness was evaluated in the span of five years by annual profit for the individual banks. The findings from the study showed a 
moderate association between bank size and profitability, and the two variables were statistically significant. The study indicated that banks retain high deposits since it had a beneficial impact on the improvement of bank's profitability in Kenya. The study's findings show that banking size is the principal determinant of bank performance and that a measuring feature of banks' competitiveness, banking size has a favourable effect on profitability. Moreover, Nzioka, and Kariuki (2021) found that in enhancing the competitive advantage of commercial banks in kenya, the issues of total quality management, strategic plan implementation must be critically looked at and be in tandem with the decision-making process. This implies that in their increase in size, banks must move in a planned strategic manner.

Ali and Ghazali (2018) conducted a similar study in Pakistan on the bank size's profitability effect for commercial banks and the Islamic banks between 2008 and 2012. Secondary data were obtained from five commercial banks and five Islamic banks, where financial statements were collected from the banking website. The association between bank size and profitability showed Islamic banks to have more profit than business banks. But the size of the bank could not be linked to Islamic banking profitability. The regression analysis results revealed that the size of the banks was associated with the profitability of commercial banks, but the link was neutral when it came to the Islamic Bank. The results also showed that business banks had a higher ROA value than Islamic banks. The T-test also showed that the bank's size influence on commercial banks was greater, whereas Islamic banks had no effect. Based on their findings, Ali and Ghazali (2018) recommended further research to achieve more accurate results of the banking situation in Pakistan by increasing the sample size of the banks. In support, Tabak, Fazio and Cajueiro (2012) conducted a study on the consequences of the competition between banks in Latin America and the effects of size and capitalisation change. Data was acquired from the Bank Scope database from 2001 to 2008; the research involved 10 Latin American nations. The study used a wide range of approaches, such as the structural behaviour (SCP) paradigm for measurement, which used a concentration aspect to depict competition because of the difficulties of determining competition. The study used Bresnahan and Panzar models to predict competition levels. The results indicated that the banks' size was nonlinear with the bank's competitiveness and that the size of the bank explained the competitive benefits, such as improving risk behaviour by using the least capital available. The analysis also found that both large and small banks had a positive association between their capital ratios. The results also demonstrated a higher risky behaviour rate, with bigger banks tending to operate in competitive markets. The regulators of larger banks are too massive to fail; thus, the majority are risk-takers because they expect the authorities to help them in the event of instability. Therefore, it can be concluded from the data that banking size has a beneficial impact on bank competitiveness, as the growth in bank size led to increased stability to gauge banks' competitiveness. In the same vein, Nazari, Pourshahabi and Kamalian, (2021) interrogated the effect of bank size on bank income ranges amongst Iranian banks. The research evaluated 8 banks in the Tehran Stock Exchange using panel econometric method (EGLS) applying the records in the period 2005 to 2018. The study found that whenever banks are faced with crisis, the impact is not significant on the resultant performance. This is explained since bank size was found to be positively correlated with loan ratio and capital adequacy index depending on size. Larger banks showed an ability to whether the crisis storms in the banking sector.

Mirza (2012) also obtained preliminary evidence describing the relationship between Pakistan's commercial banks' size, diversity and risk. The author obtained panel data from commercial banks in that country and analysed it to determine whether larger banks are more diversified compared to small banks. The results indicated that, indeed, larger banks are more diversified than small banks. Mirza (2012) established that larger banks had a stronger financial foundation than their smaller counterparts and could easily take advantage of diversification opportunities. The findings were equivocal, as there were no conclusions to this aim. The results indicated ramifications for regulator policy and risk management that ensures that banks' financial systems are stable as they are crucial components of competitiveness. A similar study was conducted by Kasman and Kasman (2016), but the authors focused on Turkish commercial banks in 2016. The 
data was collected from the first quarter of 2011 to the second trimester of 2012; thus, they were based on quarterly statistics. The study's objective was to analyse the effect of bank size and competition on the volatility of income and insolvency risk. The authors identified a methodology to evaluate the competitive impact and volatility of revenues in the Turkish banking industry. Kasman and Kasman (2016) found a negative link between bank size and earnings volatility, making large banks less exposed to dangers than smaller banks. The negative association was established when ROA and ROE were investigated in both performance measures. The study also indicated that competitiveness increases volatility in income. Finally, the analysis suggests that larger banks in Turkey are less exposed to risks than those with lower profit volatility. The results also showed that the nation's biggest banks are more efficient in maintaining the emerging market competitiveness. Therefore, larger banks in the Turkish banking sector are more competitive than smaller banks.

On the same note, Karray and Chichti (2013) conducted a study on commercial banks in fifteen developing economies. The authors analysed a panel data set consisting of information from the respective commercial banking institutions collected from 2000 to 2003. The study aimed at assessing the influence of both technique and scale efficiencies of the banks' size on their competitiveness. The Data Envelopment Approach (DEA) was the approach utilised to analyse the data, which refers to the objectives of the authors' study. Study findings suggest that larger banks show higher technical efficiency in terms of input and output than smaller banks. Therefore, larger banks can be described as competitive since they are purely technological efficient than smaller commercial banks, as established by Karray and Chichti (2013). In another study, Rahman, Zheng and Ashraf (2015) examined the effects of banking size on bank risk and regulatory capital ratios, which all aspects of banking competitiveness could be determined. The study utilised a quantitative method employing panel data (collected between 2008 to 2012) from 30 commercial banks in Bangladesh. Data were derived from Bangladeshi commercial banks' annual financial statements on their websites. The study used generalised moments methods (GMM) empirically to investigate the association between study variables, including bank size and risk-taking behaviour. The study's conclusions were that the modest capital stock of major banks and the risks compared with small banks were higher. In addition, the study indicated that the association between bank size and risk management was negative. Larger banks with a high level of capital, compared to small banks with lower capital balance levels, were less risky. The outcome was regarded as having the effect of reducing banking risk, thus boosting competitiveness as regards the size of the bank in terms of capital ratio.

Adusei (2015) also conducted a study to explore the influence of bank size and financial risk on bank stability. Data collected was restricted to only rural banks in Ghana; only 112 out of 137 rural banks were analysed. The data was obtained from the ARB Apex Bank through quarterly reports, i.e. from the first quarter of 2009 through the fourth quarter of the 2013 financial years. Results showed a positive link between the risk of funding and the stability of banks. Moreover, the larger the bank, the higher it was likely that it was aware of risk financing mechanisms such as pooling, transfers and retained funds. Therefore, larger banks are financially stable and more competitive than small banks. Neves, Proença and Dias (2020) investigated drivers of bank profitability on the Iberian Peninsula. The authors examined a sample of 66 Portuguese and Spanish banks. The authors utilised the Generalised Moment Method (GMM), with ROAA and ROAE being the basis for the performance measurement. The research results indicated that management variables largely drove financial performance in the Iberian Peninsula in terms of profitability and effectiveness. The research also showed that the relationship between bank size and bank efficiency is positive and negative. ROAA, and ROAE were positively valued by the empirical outcomes of the investigation. Neves, Proença and Dias (2020) also noted that in comparison with 2013, the number of efficient banks rose in 2014 and 2015 but dropped again in 2016. The authors concluded that the relationship between bank size and bank performance is non-linear.

Tamale and Ndegwa (2017) examined the influence of regional business diversification on the financial competitiveness of commercial banks in the country and on the function of size. The data was analysed through multiple regression analysis and chi-square testing to assess whether the direct or indirect links existed between the variables. The results showed that diversification of the 
banking sector positively and significantly affects the financial situation of the Kenyan commercial banks. Only geographical diversification substantially impacted finances for those banks that belonged to the medium-sized category. However, for larger commercial banks, not all four forms of diversification significantly affected the financial results. Therefore, the report proposed that business diversification plans should be developed, especially suited to each level of commercial banks in Kenya because no intervention would cut them off as a whole. Likewise, Githaiga (2019) conducted a study in Kenya on the relationship between the diversification of customer capital and revenues and the size of the banks. The study analysed panel data collected between the years 2008 to 2017 from 31 commercial banks in Kenya. Data was analysed through both descriptive and inferential statistics (regression analysis). The Herfindahl-Hirschman Index measured the diversification of revenues which was the independent variable. The research revealed that the revenue diversity and customer capital of business banks in Kenya are closely related. The study indicated a negative link between the income from interest and non-interest revenues, as intermediary activities resulted from non-interest revenues. Teimet, Ochieng, and Aywa (2011) examined the influence of revenue diversification on the profitability of commercial banks in Kenya, taking into consideration the influence of institutions' size. They employed quantitative methods to calculate the difference in HHI and obtained data from Kenyan commercial banks. Results showed that the Herfindahl-Hirschman Index $(\mathrm{HHI})=45$ diversified commercial banks at the greatest level, with the medium level being $\mathrm{HHI}=43$ while the small ones were at $\mathrm{HHI}=40$. The statistics above showed that Kenya's commercial banks had a volume of $0,25<\mathrm{HHI}>0,75$, whereas larger commercial banks had better return.

\section{Research Design}

\section{Research Methodology}

According to Harrison et al. (2017), a study design is an overall strategy or blueprint for the data collection, measurement, and analysis to ensure that the research problem is effectively addressed. The current study adopted an ex-post factor explanatory design to examine the relationship between the firm size in the bank competitiveness in Kenya. This research design is particularly effective since it interprets the data and assesses the current relationship between variables. To make the data easy to understand, the researcher collected the firm size and commercial bank competitiveness index data on commercial banks of Kenya from the Central Bank of Kenya (CBK) records. Therefore, the ex-post factor explanatory design was the most appropriate design since the research intends to uncover inferences or causal associations between the two variables.

\section{Data Collection and Procedure}

The collection of data entails the compilation and recording of information on the specific variables in a conventional systematic fashion that allows the investigator to provide answers and appreciate the research results. The study used secondary data from financial disclosures by the CBK. Since Commercial banks are required by law to submit accurate operational data to CBK, the researchers chose to use them as the secondary data source to assess the effect that firm size has on commercial banks competitiveness. The data gathered were acquired through a data panel for $2009-2018$. Besides, during this time, the banking industry was experiencing fast structural changes, innovation, micro and macroeconomic developments. However, only 36 banks had their data reviewed in the study, resulting in an 85.7 per cent coverage rate after six institutions were eliminated.

\section{Data Analysis}

All the data collected from CBK was screened for missing values and appropriately coded. The coded data analysed using descriptive and inferential statistics. Descriptive statistics included the mean and standard deviation. Spearman's rho correlation and linear regression equation were applied to determine the link between dependent and independent variables. The regression analysis tests was conducted to establish causal links between the size of the company and the financial performance of Kenyan commercial banks. There was a linear regression model with only two 
variables. The dependent variable was the bank's competitiveness, which was determined by the competitive index of the banks in the commercial banks of Kenya (CBK) list.

\section{Descriptive Statistics}

\section{Results and Analysis}

An analysis to identify the study variables' aggregate patterns was done by obtaining their mean, standard deviation, maximum and minimum values. This covered all the 360 objects of the study variables. The findings are presented in Table 1. The results showed that commercial banks in Kenya had a mean competitiveness index of 10.16 and the firm size index of 10.45. The standard deviation for competitiveness index and firm size were found to be 1.329 and 1.348 , respectively.

Table 1: Descriptive Statistics

\begin{tabular}{lcllll}
\hline Variable & Obs & Mean & Std. Deviation & Max. & Min. \\
\hline Competitiveness index & 360 & 10.16 & 1.329 & 13.095 & 5.242 \\
Firm Size & 360 & 10.452 & 1.348 & 14.517 & 7.103 \\
\hline
\end{tabular}

\section{Inference Statistics Correlation}

\section{Analysis}

Spearman's Rho correlation results showed that the size of the commercial banks was positively correlated with bank competitiveness index in Kenya. The results showed in the Table 2 that (rho= $0.989, \mathrm{p}<0.01)$ and competitive index. The association between the variables is significant when measured at $\mathrm{p}<0.01$.

Table 2: Spearman's Rho Correlation Results

\begin{tabular}{llll}
\hline Variable & {$[1]$} & {$[2]$} \\
\hline Competitiveness index & {$[1]$} & 1.000 & \\
Firm Size & {$[2]$} & $0.989^{* *}$ & 1.000 \\
\hline
\end{tabular}

\section{Regression Analysis}

The Table 3 below shows the results of the relationship between the competitive index due to competition and firm size.

Table 3: Regression Analysis

\begin{tabular}{lll} 
& \multicolumn{2}{c}{ Dependent Variable: Competitive Index } \\
\hline & Model 1 $(\mathrm{fe})$ & \\
\cline { 2 - 3 } & Coefficient & Prob. \\
\hline Constant & -0.077 & 0.929 \\
$\begin{array}{l}\text { Competitiveness } \\
\text { index }\end{array}$ & 0.974 & 0
\end{tabular}

With a significant $\mathrm{p}$-value $(\mathrm{p}<0.05)$, it means that the size of the commercial banks has a significant influence on commercial bank competitiveness in Kenya. The study showed that a unit increase in firm size would significantly increase commercial bank competitiveness by 0.974 points when keeping all factors constant.

\section{Discussion of Findings}

The research's broad aim was to assess the effects of firm size (commercial banks) on performance and competitiveness. The correlation results indicated that bank size had a significant positive correlation with the commercial bank competitiveness index. The results were consistent with those of Alhassan (2015), who noted that larger banks benefit from economies of scale, allowing them to take a larger share of the market, making it to be more competitive. Similarly, Laeven et al. (2015) found a positive relationship between competitiveness and the purely anticipated coverage of large 
banks. However, the findings by Kamani (2018) differed from the results of the current study and the two studies discussed above. In particular, Kamani (2018) reported that smaller banks could not handle competitiveness challenges, making the bank size correlate with competitiveness negatively.

The current study results showed that the size of the commercial banks has a positive and significant effect on commercial bank competitiveness in Kenya. The findings demonstrate that smaller banks can be handled more effectively. The results were consistent with those of Laeven, Ratnovski and Tong (2015), who indicated that in the United States (USA) and Europe, the competitiveness of business banks was directly affected by the size of the banks. Additionally, Krotel, Villadsen and Hansen (2017) showed that corporate management is linked to daily business from a public standpoint and its size. Moreover, the researcher noted that commercial management was not usually affected by size. In line with current results, Kamani (2018) evaluated the relationship between banks' size, non-traditional banking activity and the systemic risk facing European banks; the authors established that the systemic risk of smaller banks grew through depending on non-traditional operations. Hence, there was a positive relationship between banks size and banking activities. Similar results were reported by Naseri, Bacha and Masih (2019), who examined whether the size of the bank has a good or negative influence on the bank's performance. They found that bank size and performance are non-linear in relation to profitability and efficiency. Additionally, banking size was found to be equivalent to the increase in profitability and efficiency of commercial banks, which are crucial to competitiveness, both in conventional and Islamic banks.

The current study results also support those by Maina, Kiragu and Kamau (2019), who examined the relationship between bank volume and commercial bank profitability in Kenya. Their results showed a moderate association between bank size and profitability, and the two variables were statistically significant, making these results consistent with the current study. On the contrary, Ali and Ghazali (2018) study on the profitability effect of the bank size for commercial banks and the Islamic banks between 2008 and 2012 showed that the size of the bank did not link to Islamic banking profitability. The findings were consistent with the current study that the size of the banks was associated with the profitability of commercial banks; however, the link was neutral concerning the Islamic Bank. Similarly, Githaiga (2019) study on the relationship between the diversification of customer capital and revenues and the size of the banks for a period between 2008 to 2017 revealed that the revenue diversity and customer capital of business banks in Kenya are closely related.

Likewise, Teimet, Ochieng, and Aywa (2011) result supported the current study findings. Teimet, Ochieng, and Aywa (2011) examined the influence of revenue diversification on the profitability of commercial banks in Kenya, taking into consideration the influence of institutions' size and established that Herfindahl-Hirschman Index $(\mathrm{HHI})=45$ diversified commercial banks at the greatest level, with the medium level being $\mathrm{HHI}=43$ while the small ones were at $\mathrm{HHI}=40$. The results also showed that Kenya's commercial banks had a volume of $0.25<\mathrm{HHI}>0,75$, whereas larger commercial banks had better return; hence, the comparison above shows that firm size and commercial banks competitiveness have a positive and significant association. In contrast to current results, only Hakenes and Schnabel, who conducted a study to determine the relationship between bank size and competitiveness as shown in Base II Capital Agreements, reported in their results that the banks' size and competitiveness were negatively associated.

\section{Conclusions}

The current article studied the impact of company size on the financial performance of deposit holdings in Kenya together with the financial inertia in the periods of 2011 to 2018 through an analysis of panel data. As regards financial performance impacts of corporate size, the latter directly affects financial performance by the total assets using a static GLM model. The study showed that, in general, firm size had a significant effect on the competitiveness of commercial banks in Kenya. This confirms the RBV theory and ES premise that large companies would benefit better from their capital and competitive index. The work of literature and the current report found that the customer's impact upon financial results was insignificant. Concerning the financial inertia of deposit income and employing the GMM pattern, firm size has a strong direct effect on the contemporary 
performance of a year's financial performance. Building on these outcomes, microfinance investors should focus on increasing the sizes of firms so that to have an increment in the portfolio returns. They should also execute strategies that maintain good financial performance as the inertia of prior performances has affected their contemporary business results.

\section{Recommendations}

Commercial banks should consider improving their capability by increasing their firm size in diverse ways. For instance, smaller banks should undertake geographic diversification while larger banks consider asset diversification. Consequently, customers would benefit from accessible and effective services that enable banks to boost their services' efficiency and increase their performance. The study also recommends that policymakers in the banking industry should establish policy frameworks linked to their different company dimensions/sizes through bank diversification and competitiveness nexus in Kenya.

\section{Limitations of the Study and Suggestion for Future Research}

The study has two main limitations. It had only one hypothesis which a limited its scope. Again, the study was concentrated only amongst the commercial banks in Kenya. This excluded other jurisdiction where commercial banks operate across other regions. since some other relationships were not covered. Future studies should consider examining the relationship between the variables in other areas such as listed and manufacturing companies that are similar in terms of scale and interventions. This could help analysts expand their research's broad spectrum by comparing data and drawing more trustworthy conclusions. Due to macroeconomic factors, including technology developments, laws and legislative frameworks, among other things, the study recommends that a comparative study should be undertaken every fifteen years to determine whether that association remains in force. The 'causes and effects between the size of the bank and efficiency should be determined by means of a longitudinal design. This allows researchers to gain more accurate findings that lead to more dependable discoveries.

\section{Acknowledgement}

We wish to thank the individuals who made this work successful in one way or the other. First, we acknowledge the Almighty God. He divinely gave us the strength, ability and good health that enabled us to progress with this work to conclusion. Secondly are the Board of Examiners under the School of business and Human Resource Development at Rongo University, under the Dean, Professor John E. Odada, whose invaluable support and guidance form the cornerstone of this research. We remember the many constructive criticisms during face-to-face consultations, telephone discussions. They gave us pieces of advice and technical support on the modalities of research work. This enabled us to complete this research successfully. The next notable support is from the Central Bank of Kenya, which provided the data analysed in this study. The data was comprehensive and availed in a medium that was quite useful for the current research. Finally, we thank our families, who provided the emotional support throughout the research period. 


\section{References}

Abubakar Aliyu, A., \& Tasmin, B. H. (2012). The impact of information and communication technology on bankse performance and customer service delivery in the banking industry. International Journal of Latest Trends in Finance and Economic Sciences, 2(1), pp,80-90.

Adusei, M. (2015). The impact of bank size and funding risk on bank stability. Cogent Economics \& Finance, 3(1), pp.1-19.

Alhassan, A. L. (2015). Income diversification and bank efficiency in an emerging market. Enmaral Insight, Managerial Finance, 41(12), pp. 1318-1335.

Ali, S. A., \& Ghazali, Z. (2018). Impact of Firm Size on Profitability: A Comparative Study of Islamic Banks and Commercial Bank in Pakistan. Global Journal of Management And Business Research. 18(5), pp. 30-35.

Allen, L., \& Rai, A. (2009). Operational efficiency in banking: An international comparison. Journal of Banking \& Finance, 20(4), 655-672.

Bigelli, M., \& Sánchez-Vidal, J. (2012). Cash holdings in private firms. Journal of Banking \& Finance, 36(1), pp. 26-35.

Dietrich, A., \& Wanzenried, G. (2011). Determinants of bank profitability before and during the crisis: Evidence from Switzerland. Journal of International Financial Markets, Institutions and Money, 21(3), 307-327.

Eyigege, A. I. (2018). Influence of firm size on financial performance of deposit money banks quoted on the Nigeria Stock Exchange. International Journal of Economics and Financial Research, 5(9), pp. 297, 302.

Foyeke, O. I., Iyoha, F. O., \& Ojeka, S. (2015). Firm size and financial performance: A determinant of corporate governance disclosure practices of Nigerian companies. Journal of Accounting and Auditing: Research \& Practice.

Githaiga, P. N. (2019). Customer Capital and Income Diversification: An Empirical Analysis. Journal of Business Management and Economic Research, 3(11).

Hakenes, H., \& Schnabel, I. (2011). Bank size and risk-taking under Basel II. Journal of banking \& finance, 35(6), 1436-1449.

Harrison, H., Birks, M., Franklin, R., \& Mills, J. (2017, January). Case study research: Foundations and methodological orientations. In Forum Qualitative Sozialforschung/Forum: Qualitative Social Research, 18(1).

Kamani, EF, (2018), The effect of non-traditional banking activities on systemic risk: does bank size matter? Finance Research Letters.

Karray, S. C., \& Chichti, J. E (2013). Bank size and efficiency in developing countries: intermediation approach versus value-added approach and impact of non-traditional activities. Asian Economic and Financial Review, 3(5), 593.

Kasman, A., \& Kasman, S. (2016). Bank size, competition and risk in the Turkish banking industry. Empirica, 43(3), 607-631.

Kipesha, E. F. (2013). Impact of size and age on firm performance: Evidence from microfinance institutions in Tanzania.

Kisengo, Z., \& Kipchumba, S. (2016). Impact of structure-related firm characteristics on performance of microfinance institutions in Nakuru, Kenya. International Journal of Science and Research, 5 (6): 92, 99.

Krøtel, S. M., Villadsen, A. R., \& Hansen, M. B. (2017). What to do here? What to do there? The effect of change in organisation size on public management. International Public Management Journal, 20(4), 675-700.

Laeven, L., Ratnovski, L., \& Tong, H. (2016). Bank size, capital, and systemic risk: Some international evidence. Journal of Banking \& Finance, 69, S25-S34.

Laeven, L., Ratnovski, L., Tong, H., (2016) Bank Size, Capital, and Systemic Risk: Some International Evidence, Journal of Banking \& Finance Journal of Banking \& Finance, 69(1) pp25-34.

Maina, G., Kiragu, D., \& Kamau, R. E. (2019). Relationship between firm size and profitability of 
commercial banks in Kenya. International Journal of Economics, Commerce and Management, 3 (5): 249,62 .

Maina, G., Kiragu, D., \& Kamau, R. E. (2019). Relationship between firm size and profitability of commercial banks in Kenya. International Journal of Economics, Commerce and Management, 3(5): 249, 62 .

Marete, D. (2015). The relationship between firm size and financial leverage of firms listed at Nairobi securities exchange (Doctoral dissertation, University of Nairobi).

Mirza, N. (2012). Size, Diversification and Risk: Preliminary Evidence from Commercial Banks in Pakistan. Pak. J. Commer. Soc. Sci., 6(2), 282-296.

Muinamia, J. N., \& Atheru, G. (2018). Firm size, leverage, liquidity and financial performance of tier-one Commercial Banks in Kenya. Research Acies International Journal of Business and Management Studies, 2(2): 1, 15.

Mulwa, J. M. (2020). Bank Diversification and Market Valuation: An Analysis of Commercial Banks Listed in Nairobi Securities Exchange, Kenya.

Mulwa, J. M., \& Kosgei, D. (2016). Commercial bank diversification and financial performance: The moderating role of risk.

Mwangi, M. (2018). The Effect of Size on Financial Performance of Commercial Banks in Kenya. European Scientific Journal, 14(7), 373-385.

Mwangi, M. N. (2014). The effects of liquidity on the financial performance of deposit-taking microfinance institutions in Kenya (Doctoral dissertation).

Nazari, A., Pourshahabi, F., \& Kamalian, N. (2021). The Role of Banking Crisis in the Effect of Income Structure on Risk in the Iranian Banking Industry International Journal of Economics and Politics, 2(1), 117-146.

Naseri, M., Bacha, O. I., \& Masih, M. (2020). Too small to succeed versus too big to fail: how much does size matter in banking? Emerging Markets Finance and Trade, 56(1), 164-187.

Neves, M. E., Proença, C., \& Dias, A. (2020). Bank Profitability and Efficiency in Portugal and Spain: A Non-Linearity Approach. Journal of Risk and Financial Management, 13(11), 284.

Nzioka, C., \& Kariuki, P., (2021), Influence of Strategic Internal Factors on Competitive Advantage of Commercial Banks in Nairobi County, Journal of International Business and Management 4(7): 01-16.

Odusanya, I. A., Yinusa, O. G., \& Ilo, B. M. (2018). Determinants of firm profitability in Nigeria: Evidence from dynamic panel models. SPOUDAI-Journal of Economics and Business, 68(1), 43-58.

Ozcan, I., Esra, A. U. and Yener, U. (2017). The effect of firm size on profitability: Evidence from Turkish manufacturing sector. Journal of Business, Economics and Finance, 6(4): 301-08.

Rahman, M.M., Zheng, C., \& Ashraf, B.N., (2015) Bank Size, Risk-taking and Capital Regulation in Bangladesh (2015) Eurasian Journal of Business and Economics, 8 (15), 95-114.

Sritharan, V., (2015). Does firm size influence on firm's Profitability? Evidence from listed firms of Sri Lankan Hotels and Travels sector. Research Journal of Finance and Accounting. ISSN 22222847

Tamale, K. D., \& Ndegwa, J. (2017). An Analysis of the Effect of Business Diversification on the Financial Performance of Commercial Banks in Kenya. International Journal of Current Aspects in Finance (IJCAF), IV(I), 30-47.

Teimet, P. R., Ochieng D. O., \& Aywa, S., (2011) Income Source Diversification and Financial Performance of Commercial Banks in Kenya. International Journal of Business and Public Management, 1(1): 26-35

Too, I. C., \& Simiyu, E. (2019). Firms characteristics and Financial Performance of general insurance firms in Kenya. International Journal of Business Management and Finance, 2(1).

Vinals, J., Pazarbasioglu, C. Surti, J., Narain A., Erbenova M., \& Chow J., (2013). Creating a safer financial system: Will the Volcker, Vickers, and Liikanen structural measures help. IMF Staff Discussion Note 13/04. 
Willison, J., Dimitris, K., \& Hong, L. (2013). The Dynamics of US bank profitability, the responsible of banking and finance, University of St Andrews retrieved from HTTP. www. st-Andrews. ac. uk/business/rbf/workingpapers/RBF13_007. Pdf visited on 7/09.

\section{Appendixes}

Appendix 1: Document Analysis Guide

Section A: Background Information

1. Name of the commercial bank

2. The year of operation commencement

SECTION B: Document Analysis

\begin{tabular}{|l|l|l|l|l|l|l|l|l|l|l|}
\hline Parameter & \multicolumn{9}{|c|}{ YEARS } \\
\cline { 2 - 11 } & $\mathbf{2 0 0 9}$ & $\mathbf{2 0 1 0}$ & $\mathbf{2 0 1 1}$ & $\mathbf{2 0 1 2}$ & $\mathbf{2 0 1 3}$ & $\mathbf{2 0 1 4}$ & $\mathbf{2 0 1 5}$ & $\mathbf{2 0 1 6}$ & $\mathbf{2 0 1 7}$ & $\mathbf{2 0 1 8}$ \\
\hline $\begin{array}{l}\text { Total Deposits } \\
\text { (Kshs' 000,000) }\end{array}$ & & & & & & & & & & \\
\hline $\begin{array}{l}\text { Total bank Assets } \\
\text { (Kshs' 000,000) }\end{array}$ & & & & & & & & & & \\
\hline
\end{tabular}

END

\begin{tabular}{llll}
\hline S/No. & Commercial Bank & CBK Peer Group & Remarks \\
\hline 1 & Barclays Bank of Kenya Limited & Large & Operational \\
2 & Commercial Bank of Africa Limited & Large & Operational \\
3 & Co-operative Bank of Kenya Limited & Large & Operational \\
4 & Diamond Trust Bank Kenya Limited & Large & Operational \\
5 & Equity Bank (Kenya) Limited & Large & Operational \\
6 & I \& M Bank Limited & Large & Operational \\
7 & KCB Bank Kenya Limited & Large & Operational \\
8 & Stanbic Bank Kenya Limited & Large & Operational \\
9 & Standard Chartered Bank Kenya Limited & Large & Operational \\
10 & Chase Bank (K) Limited & Medium & In receivership \\
11 & Imperial Bank Limited & Medium & In receivership \\
12 & Bank of Baroda (K) Limited & Medium & Operational \\
13 & Bank of India & Medium & Operational \\
14 & Citibank N.A Kenya & Medium & Operational \\
15 & Ecobank Kenya Limited & Medium & Operational \\
16 & Family Bank Limited & Medium & Operational \\
17 & I \& M Bank Limited & Medium & Operational \\
18 & National Bank of Kenya Limited & Medium & Operational \\
19 & NIC Bank Kenya PLC & Medium & Operational \\
20 & Prime Bank Limited & Medium & Operational \\
21 & African Banking Corporation & Small & Operational \\
22 & Bank of Africa Kenya Limited & Small & Operational
\end{tabular}




\begin{tabular}{llll}
23 & Consolidated Bank of Kenya Limited & Small & Operational \\
24 & Credit Bank Limited & Small & Operational \\
25 & Development Bank of Kenya Limited & Small & Operational \\
26 & DIB Bank Kenya & Small & Operational \\
27 & First Community Bank Limited & Small & Operational \\
28 & Guaranty Trust Bank (Kenya) Limited & Small & Operational \\
29 & Guardian Bank Limited & Small & Operational \\
30 & Gulf African Bank Limited & Small & Operational \\
31 & Habib Bank A.G Zurich & Small & Operational \\
32 & Jamii Bora Bank Limited & Small & Operational \\
32 & Mayfair Bank Limited & Small & Operational \\
33 & Middle East Bank (K) Limited & Small & Operational \\
34 & M-Oriental Bank Limited & Small & Operational \\
35 & Paramount Bank Limited & Small & Operational \\
36 & SBM Bank (Kenya) Limited & Small & Operational \\
37 & Sidian Bank Limited & Small & Operational \\
38 & Spire Bank Limited & Small & Operational \\
39 & Transnational Bank Limited & Small & Operational \\
40 & UBA Kenya Bank Limited & Small & Operational \\
41 & Victoria Commercial Bank Limited & Small & Operational \\
42 & Charterhouse Bank Limited & Small & Under Statutory Mgt \\
\hline & & &
\end{tabular}

APPENDIX 2: Commercial banks in Kenya

CBK Peer Group*: This is based on the total amount of protected deposits of the bank

Source: CBK Bank Supervision Annual Report 2018 